\title{
ラットにおけるペンタクロロベンゼンとへキサクロロ ベンゼンの分布，蓄積と排泄に対する食餌制限の影響
}

（平成 5 年 4 月 7 日受理）

\begin{tabular}{|c|}
\hline 梅 垣 敬 三* \\
\hline 伊 藤 毅* \\
\hline
\end{tabular}

\section{Effects of Food Restriction on Distribution, Accumulation and Excretion of Pentachlorobenzene and Hexachlorobenzene in Rats}

\author{
Keizo Umegaki, Sachie Ikegami, Tsuyoshi Itoh and Tomio Ichikawa
}

(The National Institute of Health and Nutrition: 1-23-1, Toyama, Shinjuku-ku, Tokyo 162, Japan)

\begin{abstract}
We investigated the effect of restricted feeding $(R F)$ on the distribution, accumulation and excretion of pentachlorobenzene (PECB) and hexachlorobenzene (HCB) in rats. PECB and $\mathrm{HCB}$ have similar metabolic pathways, but HCB is poorly metaboled; the half life of HCB is few months and that of PECB is a few days. Rats were fed ad libitum (AD) or given a $40 \%$ restricted diet for 29 days. On the 21 st day (day 0 ), the rats received an equal mixture of PECB and HCB by intragastric gavage at the dose of $40 \mathrm{mg} / \mathrm{kg}$ body weight. They were killed on day $\mathrm{l}$ and day 8 after the administration. The ratio of fat tissue weight to body weight in the RF rats was smaller than that in the AD rats. Large amounts of PECB and HCB were found in fat tissue, and the total amounts in the RF rats on day 1 were lower than those in the AD rats. PECB in blood of the RF rats after the administration rapidly decreased, and residual $P E C B$ in various tissues of the $\mathrm{RF}$ rats on day 8 was also markedly lower than that of the $\mathrm{AD}$ rats. In contrast, $\mathrm{HCB}$ in blood was slightly decreased, and the decrease in the RF rats was slower than that in the $A D$ rats. In addition, $\mathrm{HCB}$ residues in various tissues of the $\mathrm{RF}$ rats on day 8 tended to be higher than those in the $A D$ rats. These results indicated that the effects of $R F$ on accumulation and on excretion of $\mathrm{PECB}$ and $\mathrm{HCB}$ are quite different.
\end{abstract}

(Received April 7, 1993)

Key words： 食餉制限 food restriction; ペンタクロロベンゼン pentachlorobenzene；へキサクロ ロベンゼン hexachlorobenzene; 分布 distribution; 蓄積 accumulation; 排泄 excretion; ガ スクロマトグラフィー (ECD) gas chromatography (ECD)

\section{暂 言}

脂溶性化学物質は吸収された後, かなりの量か脂肪組 織に分布する. 従って, 脂溶性化学物質の脂肪組織への 分布之脂肪組織から血中への移行は，その化学物質の肝 臟における代謝や排泄を修飾する極めて重要な因子にな っていると考えられる。

著者らは, 脂溶性化学物質としてペンタクロロベンゼ ン (PECB) を用い，その吸収, 蓄積, 代謝に対する種々の 栄養条件の影響について検討し, 脂肪組織量の少ない条

\footnotetext{
* 国立健康 - 栄䓹研究所：干162 東京都新宿区戸山 1-23-1
}

件では，PECB の排泄が六進することを報告しだ佔． このような PECB で認めた脂肪組織量の少ない条件に おけるその排泄の促進が，極めて代謝されにくい脂溶性 化学物質に対しても同様に認められるか否かは興味ある 問題である.

ヘキサクロロベンゼン (HCB) はその構造並びにラッ 卜肝淢における代謝経路が PECB と類似している脂溶 性化学物質である ${ }^{6), 7)}$. しかし, HCB は, PECBに比べて 極めて代謝されにくく，蓄積性がある。ラットにおける 半減期は, $\mathrm{PECB}^{8)}$ が約 1 2 日であるのに対して, $\mathrm{HCB}^{9)}$ は約 3 か月であることが報告されている。 


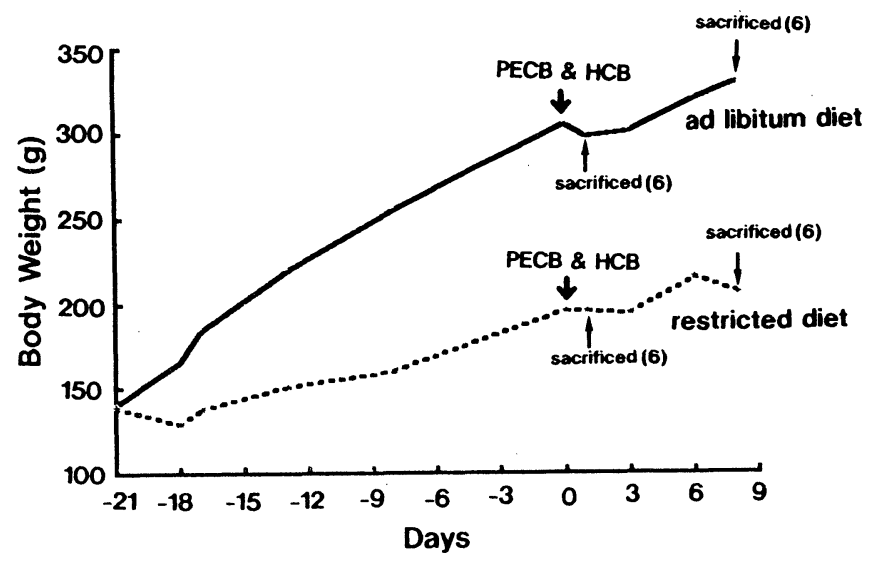

Fig. 1. Changes in body weight

Rats were fed either ad libitum or a $40 \%$ restricted diet for 29 days. On the 21 st day (day 0$)$, the rats were orally administered an equal mixture of PECB and $\mathrm{HCB}(40 \mathrm{mg} / \mathrm{kg}$ body weight), and were sacrificed on day 1 or on day 8 after the administration.

\section{Body Weight}

a) Day 1

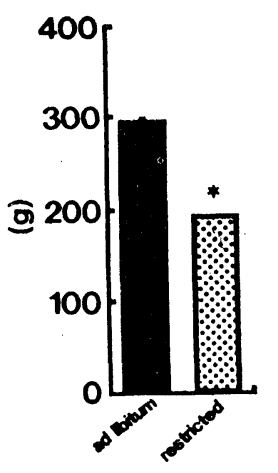

b) Day 8

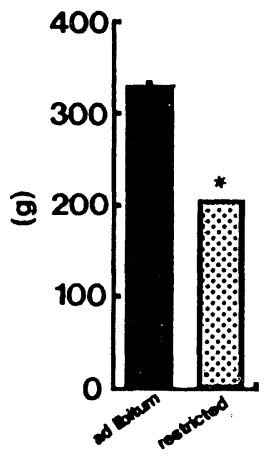

Relative Liver Weight
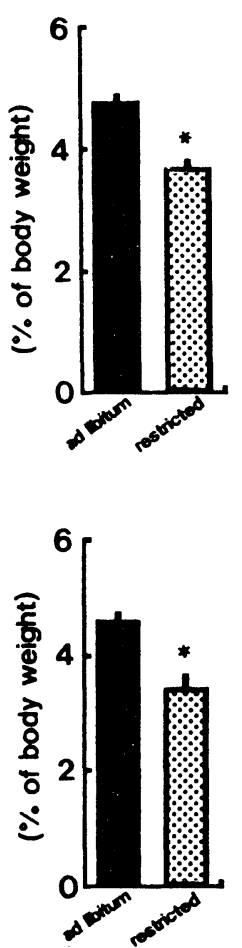

Relative Fat Tissue Weight

Perirenal Epididymal
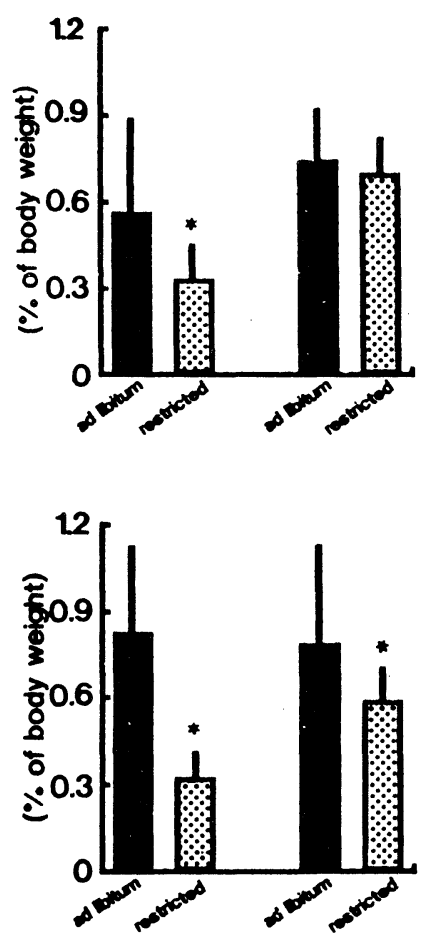

Fig. 2. Body weight and relative tissue weight

Each column and vertical bar indicates the mean \pm SE for $5 \sim 6$ rats

* Significance $p<0.05$ 
そこで本実験では，食餪制限の有無により脂肪組織量 の異なるラットを作製し，そのラットにおける $\mathrm{HCB}$ と PECB の体内分布と排泄を比較検討した。 なお, $\mathrm{HCB}$ と PECB は同時に 1 回経口投与し, 同じラットにおいて $\mathrm{PECB}$ と $\mathrm{HCB}$ の分布と排泄が比較できるようにした。

\section{実鋻方法}

\section{1. 試 䔉}

PECB と HCB は東京化成(株)のむのをメタノールで 3 回再結晶させて精製した. PECB と HCB はそれぞれ の濃度が $10 \mathrm{mg} / \mathrm{ml}$ になるように大豆油に溶解した。

\section{2. 実臨動物}

6 週齢の SD 系雄ラット（日本クレア(株)）を 1 群 12 匹として，食期制限をしない群と $40 \%$ の食慨制限をす る群の 2 群に分け, 市販粉末飼料 (CE-2, 日本クレア (株)）で 29 日間飼育した。食餉制限ラットの飼料の量 は，前日に食餪制限しないラットが攝取した飼料の量の $60 \%$ に設定した. $40 \%$ の食慨制限は，Fig. 1 に示した ようにラットの体重がわずかながら増加する条件であ る. PECB と HCB は，実験開始 3 週間目にそれぞれの
投与量が $20 \mathrm{mg} / \mathrm{kg}$ 体重になるように同時に 1 回経口 投与した. 各群のラットは, 投与 24 時間後に 6 匹, 投与 後 8 日後に 6 匹解剖し, 肝荗, 腎臟, 脳と脂肪組織（腎

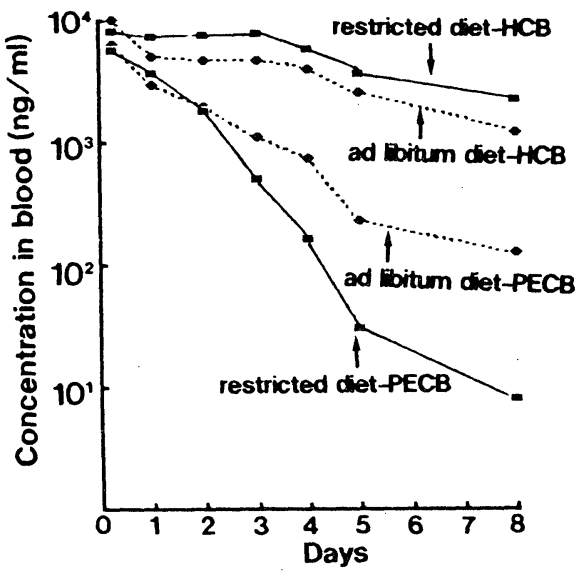

Fig. 3. Concentrations of $\mathrm{PECB}$ and $\mathrm{HCB}$ in blood through time

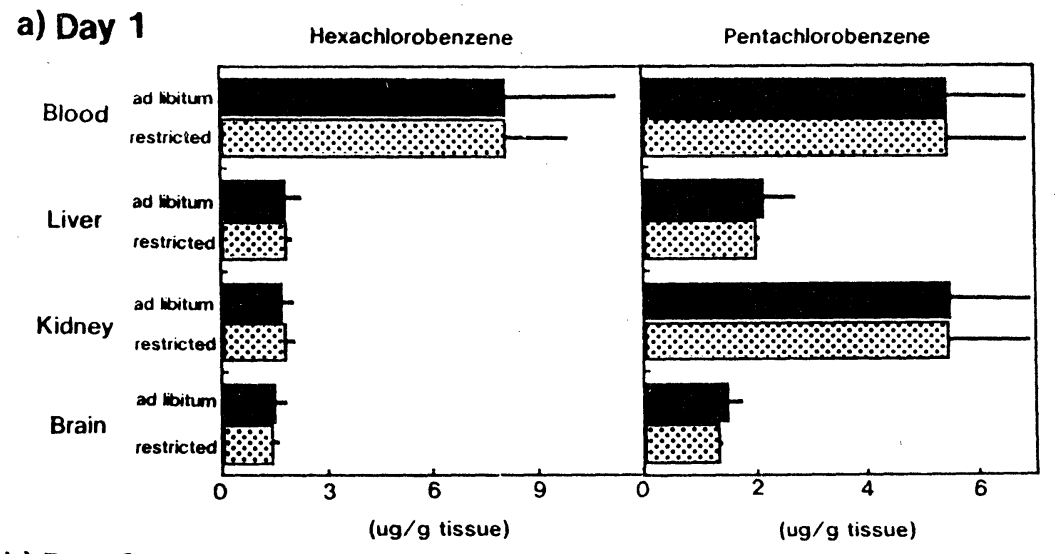

b) Day 8

Hexachlorobenzene

Pentachlorobenzene

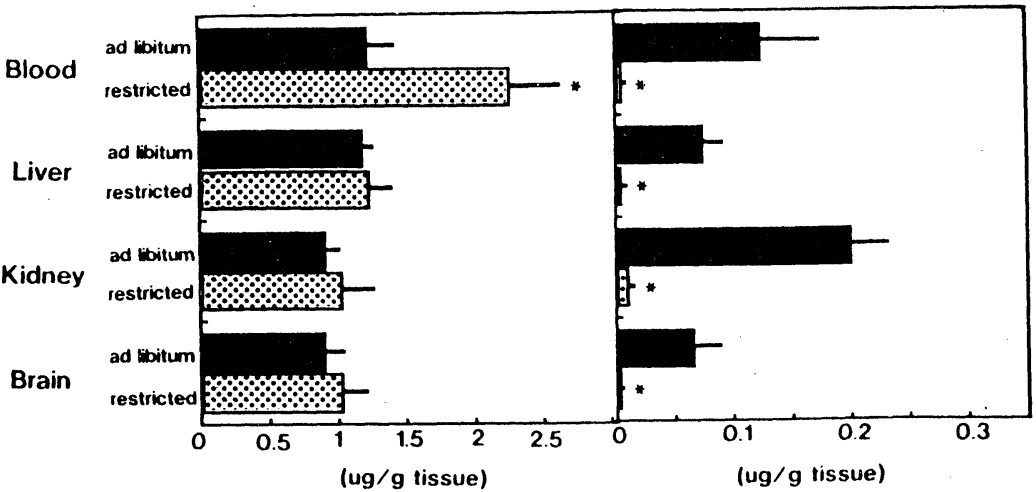

Fig. 4. Concentrations of PECB and HCB in blood, liver, kidney, and brain on day 1 and on day 8 after the administration

Each column and horizontal bar indicates mean $\pm \mathrm{SE}$ for $5 \sim 6$ rats.

* Significance $p<0.05$. 
a) Day 1

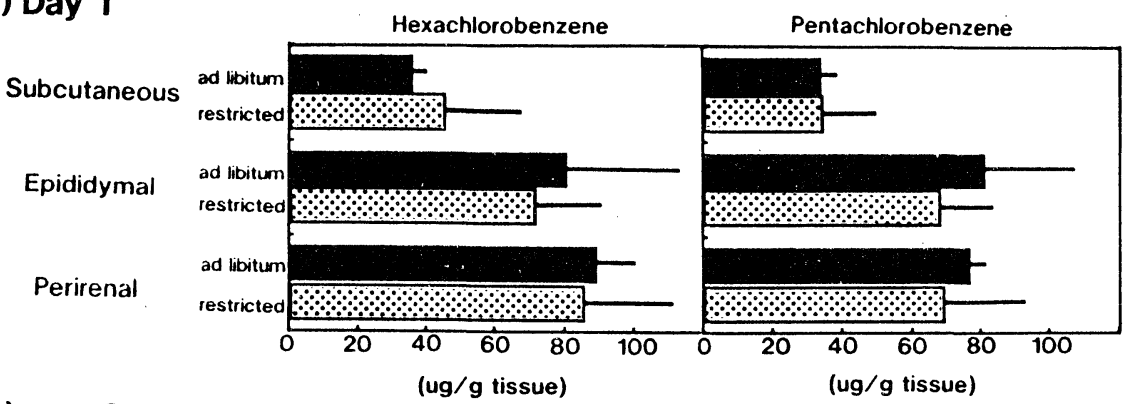

b) Day 8

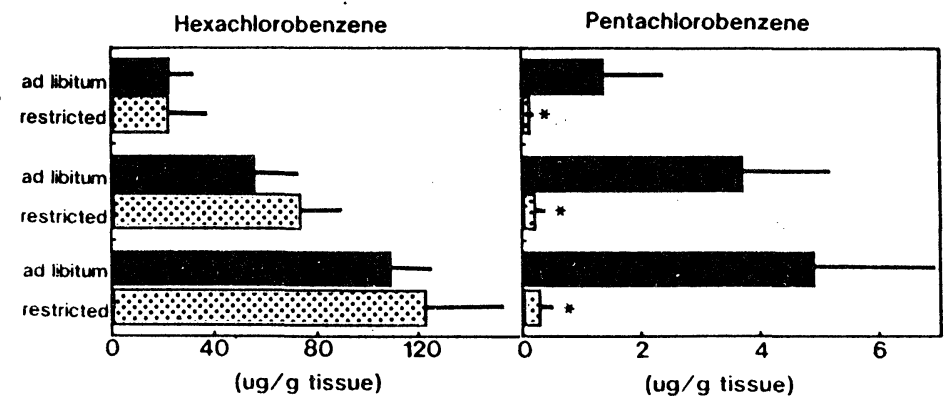

Fig. 5. Concentrations of $\mathrm{PECB}$ and $\mathrm{HCB}$ in various fat tissues on day 1 and on day 8 after the administration

Each column and horizontal bar indicates mean \pm SE for $5 \sim 6$ rats.

* Significance $p<0.05$.

周囲脂肪, 副睪丸脂肪, 右腹部の皮下脂肪）を摘出した。 また，8日目に解剖したラットについては，投与後から 経日的に䔬と尾静脈血l $0.01 \sim 0.1 \mathrm{ml}$ を採取した.

\section{3. 組織中の PECB と HCB の分析}

血液, 臟器, 脂肪, 粪中の PECB と $\mathrm{HCB}$ は, 既報の方 法 $^{8)}$ によりへキサン抽出し， ECD 検出器を付けたガスク ロマトグラフィーにより分析した。 ただし, 臟器, 脂肪, 䔬中のへキサン抽出液については，その $0.1 〜 0.5 \mathrm{ml}$ を フロリジルカラム $(0.5 \mathrm{~g}$ のフロリジルに $0.2 \mathrm{~g}$ の無水硫 酸ナトリウムを重層したカラム) に通し，更にへキサン $5 \mathrm{ml}$ を通して PECB と HCB を溶出させた。この溶什液 を全量 $10 \mathrm{ml}$ にし，適宜希釈して測定用試料とした。化 合物の濃度が薄い場合, 溶出液に $0.2 \mathrm{ml}$ のデカン溶液 (50 mg/ml のへキサン溶液) を加えて約 $40^{\circ}$ で減圧濃 縮した. デカンの添加により，減圧濃縮操作において PECB と HCB が飛散するのを防ぐことができた.

\section{4. 統計処理}

結果は平均と標準誤差で示し，有意差検定はAspin と Welch の検定 ${ }^{(0)} に よ り$ 行った.

結 果

Fig. 2 に化合物投与 1 日後と 8 日後に解剖したラッ トの体重, 体重当たりの肝臟重量と脂肪組織重量を示し た。制限食群では体重当たりの朋䐟重量と脂肪重量が小 さく，特に 8 日後の腎周囲脂肪量は無制限食群の $1 / 2$
以下の值であった。無制限食群の腎周囲脂肪量は投与 1 日目から投与 8 日目にかけて増加していた。

無制限食群と制限食群の血中 PECB 濃度は共に急激 に低下し，その低下は制限食群で著しかった (Fig. 3)。一 方，血中 HCB 濃度はいずれの群においても緩やかに低 下し，その低下はPECB の場合と異なり制限食群におい てより緩やかであった。この血中濃度の低下から計算し た半減期は，PECB では制限食群が約 18 時間，無制限 食群が約 31 時間, HCB では制限食群が約 91 時間, 無 制限食群が約 65 時間であった。 PECBの血中半減期の 值は，PECB を笚独投与して食餉制限を行った前回の奏 験 ${ }^{1)}$ 5)において得られた値とほぼ類似していた。

$\mathrm{PECB}$ と $\mathrm{HCB}$ の投与 1 日後と 8 日後における血液。 肝臟，腎堿，脳，脂肪中の PECB と HCB の濃度を Fig. 4 と 5 に示した。 $\mathrm{PECB}$ と $\mathrm{HCB}$ がほぼ均一に体内に分 布していると考えられる投与 1 日後において, PECB と $\mathrm{HCB}$ の組織 $1 \mathrm{~g}$ 中の濃度は, いずれの組織においても 2 群間に差異がなかった，投与 8 日後においては，PECB 濃度がいずれの組織においても制限食群で著しく低かっ た。これに対して HCB 濃度は制限食群でむしろ高い傾 向があり，血中濃度は有意に高かった。これらの結果は， 経日的な血中濃度の結果 (Fig. 3) とよく一致していた. 脂肪組織中の HCB 濃度を投与 1 日後之 8 日後において 比較したとき, いずれの群においても 8 日後の腎周囲脂 


\section{a) Day 1}

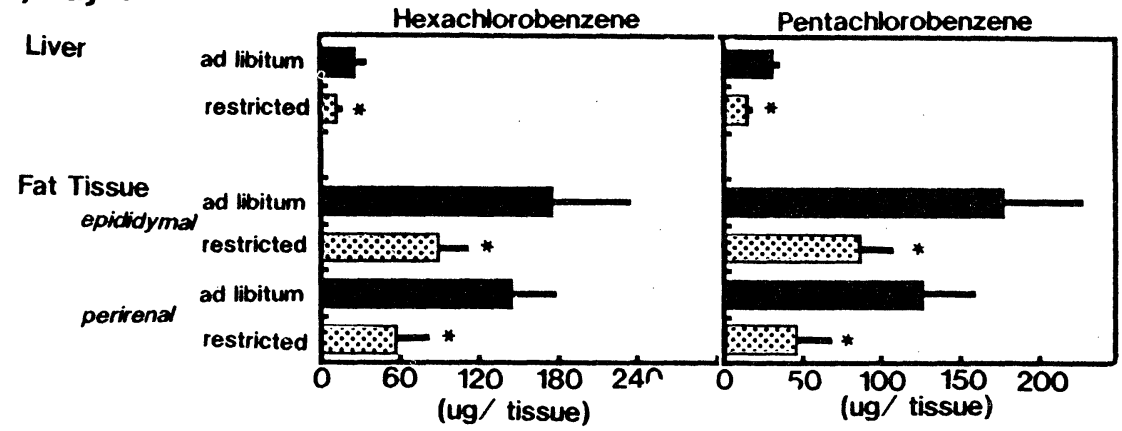

b) Day 8

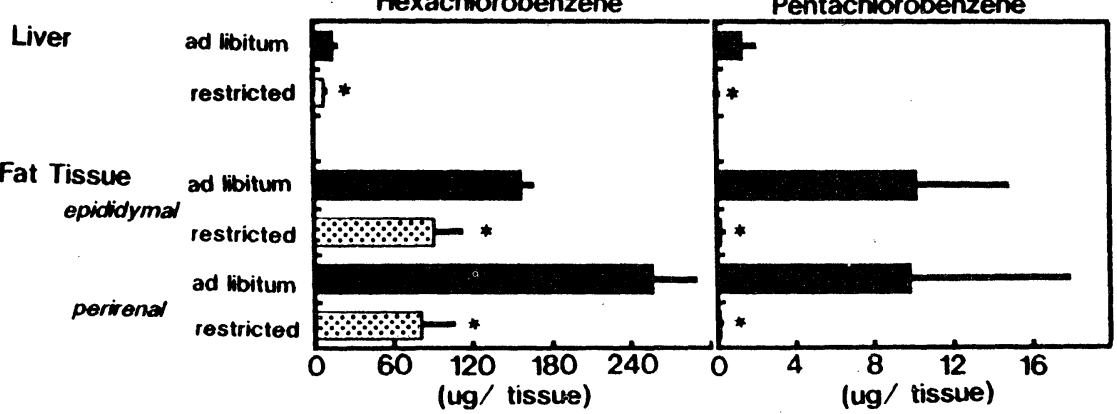

Fig. 6. Amounts of PECB and HCB existed in liver, epididy mal and perirenal fat tissue on day 1 and on day 8 after the administration.

Each column and horizontal bar indicates mean \pm SE for $5 \sim 6$ rats.

* Significance $p<0.05$

肪中の濃度が投与 1 日後の值よりも高くなっていた

(Fig. 5).

組織全体に存在する PECB と HCB の含量を肝臟と二 つの脂肪組織において計算し，その結果をFig. 6 に示し た。脂肪組織量の少ない制限食群の PECB と HCB 含量 は，投与 1 日後と 8 日後ともに無制限食群よりも有意に 少なかった．脂肪組織中の HCB 含量は，投与 1 日後よ りも投与 8 日後において高くなり, 特に無制限食の腎周 囲脂肪中の含量は著しく増加した。

化合物投与後の PECB と HCB の䔬中排泄率を測定 し，その結果をFig. 7 に示した. いずれの群においても $\mathrm{PECB}$ と $\mathrm{HCB}$ の粪中排泄率は投与 1 日目が最も多かっ た。また, PECBに比べて HCB の排泄率は高かった。無 制限食群に対して, 制限食群の HCB の粪中排泄率は, 投与 1 日後では低かったが 2 日目以降は高かった。

\section{考察}

PECB の代謝，排泄に対する食䬣制限の影響を検討し た著者らの以前の実験は，食餌制限を PECB 投与 1 週 間前，または投与直後から行ったが市，5)，今回の実験は， 化合物投与 3 週間前から行った。 そして，比較的代謝さ れやすい PECB と極めて代謝されにくい HCB を同時投 与し，それらの体内分布，蓄積並びに排泄に対する食餉

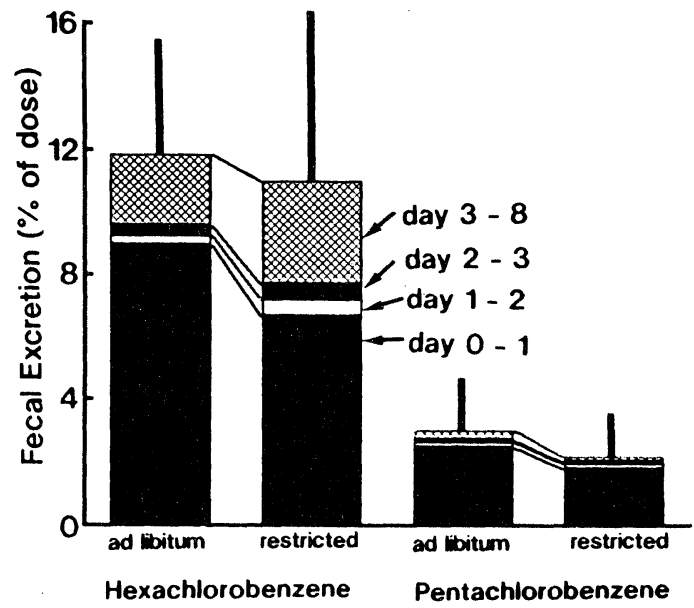

Fig. 7. Fecal excretion of PECB and HCB through time

The excretion was caluculated as \% of dose. Each column and vertical bar indicates mean $\pm S E$ for $5 \sim 6$ rats.

制限の影響を比較検討した。 その結果, PECBに関して は前回の結果 ${ }^{1)}{ }^{5)}$ と同様に, PECB の経日的な血中濃度 
と投与 8 日後の組織中含量が制限食群において著しく 低下した (Fig. 3〜6). 一方, HCB に関しては, その経日 的な血中濃度並びに投与 8 日後の各組織中濃度がむし ろ制限食群において高かった。 PECB と HCB はラット 肝脸における代謝経路が類似していると報告されてい る6).7). それ故,これらの食餌制限による $\mathrm{PECB} と \mathrm{HCB}$ の分布と排泄の違いには，それらの化合物の代謝のされ やすさの違いが関係していると考えられる.

食餌制限による PECB の排泄の促進には，食餌制限に よる脂肪組織量の低下と肝㙎薬物代謝酵素活性の増加が 関係していると思われる. ラットに 25～50\% の食慨制 限を 28 又は 45 日間行ったとき，肝蔵の P-450 含量と モノオキシゲナーゼ活性の高くなることが報告されてい $3^{111.12)}$. また, 食慨制限による P-450 の増加は, デキサ メサゾンで誘導され，クロロベンゼン代謝にも関係する P-450 III A 1 の増加に対応することが報告されてい る ${ }^{13) .14)}$. 一方, Fig. 4〜6 の結果で示されるように, 制限 食群ではPECB の蓄積に重要な脂肪組織量が少なかっ た.このため PECB の脂肪組織への分布量が少なくなる ことで血液や肝葴への分布量が多くなり，その結果とし て PECB の肝荿薬物代謝醭による代謝が速やかに行 われたと考えられる。

HCB に関しても PECB と同様, 制限食群における脂 肪組織量の低下は， HCB の脂肪組織への分布量を少な くするとともに，脂肪組織から血中への HCB の移行を 起こりやすくし，肝臓薬物代謝酵素による代謝を受けや すい状態にしていたと思われる. HCB の血中濃度が, 投 与 8 日目において制限食群で有意に高かった結果 (Fig. 4) は, 脂肪組織量の少ない条件において HCB の脂肪か ら血中への移行が起こりやすかったことを示唆してい る. また, PECB と同様に HCB を代謝する肝臟薬物代 謝酵素活性が制限食群において増加していた可能性もあ る. しかし, HCB の場合, その極めて代謝されにくい性 質のため, PECBのような排泄の促進が起こらなかった と考えられる.

著しい食郋制限や絶食などによる脂肪組織量の低下 は, 難代謝性脂溶性化学物質の脂肪組織から脳組 織への再分布を起こすことが知られている(15) 17). Villeneuve ${ }^{15)}$ は HCB を投与したラットに $75 \%$ の食䭒 制限を行った時, HCB が脂肪組織から他の組織に再分 布し，特に脳中の HCB 濃度が高くなることを報告して いる. Ecobichon ${ }^{16)}$ らも脂溶性で代謝されにくい化合物 であるDDTをひな鳥に投与した後，絶食を行った実験 において, DDT か脂肪組織から他の組織に再分布する ことを報告している．大柴と川北 ${ }^{17)}$ は $\mathrm{BHC}$ をラットに 投与後絶食を行ったとき，代謝されやすい $\gamma$-BHC の組 織内濃度は低下するが, 代謝されにくい $\beta$-BHC は再分 布を起こし, 特に脳中の含量が増加することを報告して いる. 今回の著者らの食䬣制限の実験において, 脂肪組
織量の低下による HCB の脂肪組織から脳などへの明確 な再分布は認められなかった。これは，食期制限が $40 \%$ と比較的軽かったためと思われる.

Fig. 7 に示した PECB と HCB の䔬中への排泄は，投 与 1 日目の主に未吸収分の排泄と投与 2 日〜8 日目まで の一旦吸収された化合物の腸管からの排泄分に分けて考 えられる. 制限食群では投与 2〜8 日の HCB の排泄量 が多かった。これは，いったん吸収された HCB が，食餌 制限により排泄されやすくなったことを意味していると 思われる. HCB は腸間循環すること ${ }^{18)}$, 食慨制限ラット では胆汁排泄量並びに胆汁量が多くなることがそれぞれ 認められている ${ }^{19)}$. このようなことが食慨制限群で認め られる $\mathrm{HCB}$ の投与 2〜8 日の䔬中排泄率増加に関係し ていると考えられる. HCB の場合, 肝堿における代謝は 極めて受けにくいため，この食䭒制限による HCB の䔬 中排泄量の増加は重要な意味を持つと思われる.

本研究は環境庁国立機関公害防止等試験研究費により 行ったものであり関係各位に感謝致します.

\section{文献}

1) 梅垣敬三, 市川富夫: 食衛誌. 31, 227 232 (1990).

2) 梅坦敬三，市川富夫：同上 31, 485 490 (1990).

3）池上幸江，土橋文江，梅垣敬三，市川富夫：同上 32,420 〜26 (1991).

4) 土橋文江, 池上幸江, 梅垣敬三，市川富夫：同上 33,241 $\sim 246$ (1992).

5) Umegaki, K., Ikegami, S., Ichikawa, T.: J. Nutr. Sci. Vitaminol. 39, 11 22 (1993).

6) Stewart, F.P., Smith, A. G.: Biochem. Pharmac. 36, 2,232 2,234 (1987).

7) Den Besten, C., Peters, M. M. C. C., Van Bladeren, P. J.: Biochem. Biophys. Res. Commun. 163, 1,275 1,281 (1989).

8）梅垣敬三，市川富夫：衛生化学 35, 360～364 (1988)

9) Rozman, K., Mueller, W., Iatropoulos, M., Coulston, F., Korte, F.: Chemosphere 4, 289 298 (1975).

10) 吉村 功編：“毒性, 薬効データの統計解析” p. $28 \sim 40$ (1989), サイエンティスト社.

11) Hashmi, R. S., Siddiqui, A. M., Kachole, M. S., Pawar, S. S.: J. Nutr. 116, 682 688 (1986).

12) Sachan, D. S.: Biochem. Biophys. Res. Commun. 104, 984 989 (1982).

13) Leakey, J. E. A., Cunny, H. C., Bazare, J. Jr., Webb, P. J., Feuers, R. J., Duffy, D. H., Haer, R. W.: Mech. Ageing Dev. 48, 145 155 (1989).

14) Den Besten, C., Smink, M.C.C., De Vries, E. J., Van Bladeren, P. J.: Toxicol. Appl. Pharmacol. 108, 223 233 (1991)

15) Villeneuve, D. C.: Toxicol. Appl. Pharmacol. 31, 313 319 (1975).

16) Ecobichon, D. J., Saschenbrecker, P. W.: Toxicol. Appl. Pharmacol. 15, 420 432 (1969). 
17）大柴恵一，川北兵蔵：食街誌，13，189～194 (1972).

18) Rozman, K., Rozman, T., Greim, H.: Toxicology. 22, 33 44 (1981).
19) Tuchweber, B., Perea, A., Ferland, G., Yousef, I. M.: Life Sci. 41, 2,091 2,099 (1987). 